\title{
Implementasi Pembelian Kredit Bahan Baku Material Menggunakan Aplikasi MYOB Accounting V18 Pada PT Mitra Metal Sejati
}

\author{
Arif Maulana Yusuf ${ }^{1}$, Yeny Rostiani ${ }^{2}$, Rahmat Gunawan ${ }^{3}$, Renanda Claudia ${ }^{4}$ \\ 1,2,4Program Studi Komputerisasi Akutansi, STMIK Rosma, Karawang Jawa Barat, Indonesia \\ ${ }^{3}$ Program Studi Manajemen Informatika, STMIK Rosma, Karawang Jawa Barat, Indonesia \\ Email: arif@,rosma.ac.id
}

\begin{abstract}
$A B S T R A C T$
PT Mitra Metal Sejati is a company engaged in mechanical services and fabrication machining. In carrying out its business activities, the company requires the purchase of raw materials to be able to carry out its activities. Recording credit purchases is an important part of a company because later the recording is related to debts which are the obligations of a company. The purpose of this study is to provide fast and accurate computerized purchase and debt information. The research methodology that the author uses, there are several stages starting with planning, data collection, data processing, and data migration to the MYOB Accounting Plus V18 application. The recording of the purchase of raw materials at PT Mitra Metal Sejati still uses Microsoft Excel and has not been computerized so mistakes often occur. Errors or problems that occur at PT Mitra Metal Sejati such as: inputting accounts payable and making Purchase Orders (POs) as well as credit purchase reports both names of suppliers, incoming invoice numbers and nominal still use Microsoft Excel so that sometimes data input errors occur. As for these problems and with the development of the company, it needs a good information system to support its business activities, especially in purchasing credit which will be related to company debt. Implementing a credit and debt purchase report presentation at PT Mitra Metal Sejati using the MYOB Accounting Plus V18 accounting application. So that it can make it easier, faster, in recording credit purchases and presenting purchase and debt reports, and these reports can be used as decision making by management.
\end{abstract}

Keywords: Accounting, Computerized Accounting, Credit Purchase, MYOB Accounting Plus V18, Application

\begin{abstract}
ABST RAK
PT Mitra Metal Sejati merupakan salah satu perusahaan yang bergerak dalam bidang jasa mekanikal dan machining fabrikasi. Dalam melakukan kegiatan usahanya perusahaan membutuhkan pembelian bahan baku material untuk dapat menjalankan kegiatannya. Pencatatan pembelian kredit merupakan bagian penting dalam suatu perusahaan karena nantinya pencatatan tersebut berkaitan dengan hutang yang merupakan kewajiban sebuah perusahaan. Tujuan penelitian ini menyajikan informasi pembelian dan hutang secara terkomputerisasi yang cepat dan akurat. Metodologi penelitian yang penulis gunakan terdapat beberapa tahapan diawali dengan perencanaan, pengumpulan data, pengolahan data, dan migrasi data ke aplikasi MYOB Accounting Plus V18. Pencatatan pembelian bahan baku material pada PT Mitra Metal Sejati masih menggunakan Microsoft Excel dan belum terkomputerisasi sehingga sering terjadi kesalahan. Kesalahan atau permasalahan yang terjadi pada PT Mitra Metal Sejati seperti: penginputan hutang usaha dan membuat Purchase Order (PO) serta laporan pembelian kredit baik nama supplier, nomor invoice masuk dan nominal masih menggunakan Microsoft Excel sehingga kadang terjadinya kesalahan penginputan data. Adapun dari permasalahan-permasalahan tersebut dan dengan semakin berkembangnya perusahaan membutuhkan Sistem Informasi yang baik untuk menunjang kegiatan-kegiatan usahanya khususnya dalam pembelian kredit yang nantinya berhubungan dengan utang perusahaan. Mengimplementasikan suatu penyajian laporan pembelian kredit dan utang pada PT Mitra Metal Sejati menggunakan aplikasi akuntansi MYOB Accounting Plus V18. Sehingga dapat mempermudah, mempercepat, dalam pencatatan pembelian kredit serta menyajikan laporan pembelian dan utang, dan laporan tersebut dapat digunakan sebagai pengambilan keputusan oleh manajemen.
\end{abstract}

Kata Kunci: Akuntansi, Komputerisasi Akuntansi, Pembelian Kredit, MYOB Accounting Plus V18, Aplikasi 


\section{Pendahuluan}

Perkembangan teknologi informasi pada era globalisasi saat ini, telah berkembang pesat[1]. Dimana hampir semua bidang usaha telah menggunakan dan mengembangkan sistem informasi dengan sedemikan rupa untuk menunjang aktivitas usahanya yang lebih baik. Peranan sistem akuntansi dalam aktivitas bisnis sangatlah penting untuk menangani kegiatan operasional perusahaan[2]. Sistem akuntansi dirancang untuk memberikan pengawasan guna menjamin semua transaksi telah dicatat secara tepat, valid, akurat, dan dapat melindungi aktivitas perusahaan serta untuk kepentingan pengambilan keputusan[3].

Perusahaan dalam menjalankan usahanya membutuhkan bahan baku material untuk kepentingan produksi. Adapun bahan baku yang diperoleh didapatkan dengan cara melakukan transaksi pembelian baik secara tunai ataupun kredit[4]. Untuk kegiatan tersebut tentunya perusahaan akan melibatkan pihak eksternal, salah satunya adalah supplier. PT Mitra Metal Sejati merupakan salah satu perusahaan yang bergerak dalam bidang jasa mekanikal dan machining fabrikasi. Perusahaan menyediakan peralatan-peralatan untuk keperluan teknik, peralatan listrik, dan spare part mesin untuk keperluan customer dalam sekala kecil maupun besar.

Pencatatan pembelian bahan baku material pada PT Mitra Metal Sejati masih menggunakan Microsoft Excel dan belum terkomputerisasi sehingga sering terjadi kesalahan. Kesalahan atau permasalahan yang terjadi pada PT Mitra Metal Sejati seperti: penginputan hutang usaha dan membuat Purchase Order (PO) serta laporan pembelian kredit baik nama supplier, nomor invoice masuk dan nominal masih menggunakan Microsoft Excel sehingga kadang terjadinya kesalahan penginputan data. Adapun dari permasalahan-permasalahan tersebut dan dengan semakin berkembangnya perusahaan membutuhkan Sistem Informasi yang baik untuk menunjang kegiatan-kegiatan usahanya terutama dalam pembelian kredit yang nantinya berhubungan dengan utang perusahaan, maka penulis tertarik untuk mengimplementasikan suatu penyajian laporan pembelian kredit dan hutang pada PT Mitra Metal Sejati menggunakan aplikasi akuntansi MYOB Accounting Plus V18.

Seperti penelitian sebelumnya pada UD. Praktis menggunakan MYOB dalam pencatatan penjualan dan laporan piutang terbukti bahwa proses dapat lebih cepat dan akurat, dikarenakan sudah secara otomatis proses di lakukan oleh sistem, dimana laporan piutang dapat setiap saat di lihat pada komputer, aplikasi akuntansi juga memiliki ketelitian yang tinggi, sehingga dapat mengurangi kelasahan-kesalahan yang terjadi pada proses pengolahan data secara manual. Sehingga dapat disimpulkan aplikasi MYOB dapat mempermudah proses pengolahan data dan penyusunan laporan yang di butuhkan perusahaan.[5]

Adapun permasalahan yang ditemukan pada PT Mitra Metal Sejati dalam penelitian ini adalah sebagai berikut:

1. Sistem akuntansi pembelian kredit pada PT Mitra Metal Sejati masih menggunakan Microsoft Excel dan belum terkomputerisasi.

2. Penginputan utang usaha dan membuat Purchase Order (PO) serta Laporan Pembelian Dan Hutang (LPDH) baik nama supplier, nomor invoice masuk dan nominal masih menggunakan Microsoft Excel sehingga kadang terjadinya kesalahan penginputan data.

\section{Kerangka Teoritis Dan Pengembangan Hipotesis}

\section{Definisi Akuntansi}

Akuntansi adalah proses dari transaksi yang dibuktikan dengan faktur, lalu dari transaksi dibuat jurnal, buku besar, neraca lajur, kemudian akan menghasilkan informasi dalam bentuk laporan keuangan yang digunakan pihak-pihak tertentu[6]. Akuntansi dapat didefinisikan sebagai 
suatu disiplin yang menyediakan informasi yang diperlukan untuk melaksanakan kegiatan secara efisien dan mengevaluasi kegiatan-kegiatan suatu entitas[7]. Maka dengan demikian akuntansi merupakan kegiatan mengumpulkan, mengindentifikasi, mencatat, dan melaporkan setiap kegiatan transaksi keuangan untuk dapat digunakan oleh pihak tertentu sebagai pengambilan keputusan.

\section{Sistem Informasi Akuntansi}

Sistem Informasi Akuntansi merupakan sistem berbasis komputer yang dirancang untuk mentransformasi data akuntansi menjadi informasi, yang mencakup siklus pemrosesan transaksi, penggunaan teknologi informasi, dan pengembangan sistem informasi[8]. Sistem informasi akuntansi adalah sebuah sistem yang memproses data dan transaksi guna menghasilkan informasi yang bermanfaat untuk merencanakan, mengendalikan, dan mengoperasikan bisnis [9]. Maka sistem informasi akuntansi merupakan sistem yang berbasis komputer yang memiliki komponen perangkat input, information processor, information storage dan perangkat output[10] sehingga dapat memproses data akuntansi dan transaksi untuk menghasilkan informasi yang bermanfaat bagi mengoperasikan bisnis.

\section{Pembelian Kredit}

Sistem pembelian kredit merupakan sistem pembelian dimana pembelian barang dengan pembayaran tempo atau menunda pembayaran atau kredit serta pembayarannya dilakukan setelah barang diterima pembeli[11]. Jumlah dan jatuh tempo pembayarannya disepakati oleh kedua pihak [12]. Risiko kredit merupakan risiko yang muncul dikarenakan debitur tidak membayar semua atau sebagian piutang atau tidak membayar secara tepat waktu dan akan menyebabkan kerugian Perusahaan[13].

\section{Aplikasi MYOB}

MYOB merupakan program yang dapat menghasilkan laporan keuangan dengan lebih teliti, benar, dan dapat mengurangi kesalahan yang dilakukan dengan menggunakan pencatatan secara manual, sehingga dapat membatu perusahaan menghasilakn laporan keuangan yang terkomputerisasi secara tepat dapat diperoleh selama satu periode[14]. MYOB Accounting merupakan software akuntansi terpadu yang dibuat oleh MYOB Limited. Software ini sangat cocok diterapkan di Indonesia untuk perusahan berskala kecil dan menengah[15]. Berdasarkan pengertian diatas maka MYOB merupakan software akuntansi yang digunakan untuk menghasilkan laporan keuangan secara komputerisasi yang tepat selama satu periode.

\section{Metode Penelitian}

Metodologi penelitian yang penulis gunakan terdapat beberapa tahapan diawali dengan perencanaan, pengumpulan data, pengolahan data, dan migrasi data ke aplikasi MYOB Accounting Plus V18.

1. Perencanaan

Pada tahap perencanaan, penulis membuat susunan penelitian terhadap masalah yang akan diteliti. Perencanaan penelitian dibutuhkan untuk menunjang pencapaian tujuan.

2. Pengumpulan data 
Pada tahap pengumpulan data, penulis memerlukan pengamatan serta observasi langsung pada perusahaan untuk mengetahui permasalahan yang ada, seperti kebutuhan bardware, kebutuhan software dan kebutuhan ornag sebagai operator nantinya. Sehingga penulis mendapatkan informasi dari pengumpulan data tersebut.

3. Pengolahan data

Pada tahapan ini, penulis mengindentifikasi data-data yang telah dikumpulkan dari perusahaan.

4. Migrasi Data Ke Aplikasi MYOB

Pada tahapan ini dimulai dengan cara menginstal aplikasi MYOB pada komputer. Untuk lebih jelasnya berikut merupakan bagan tahapan-tahapan migrasi data ke aplikasi MYOB:

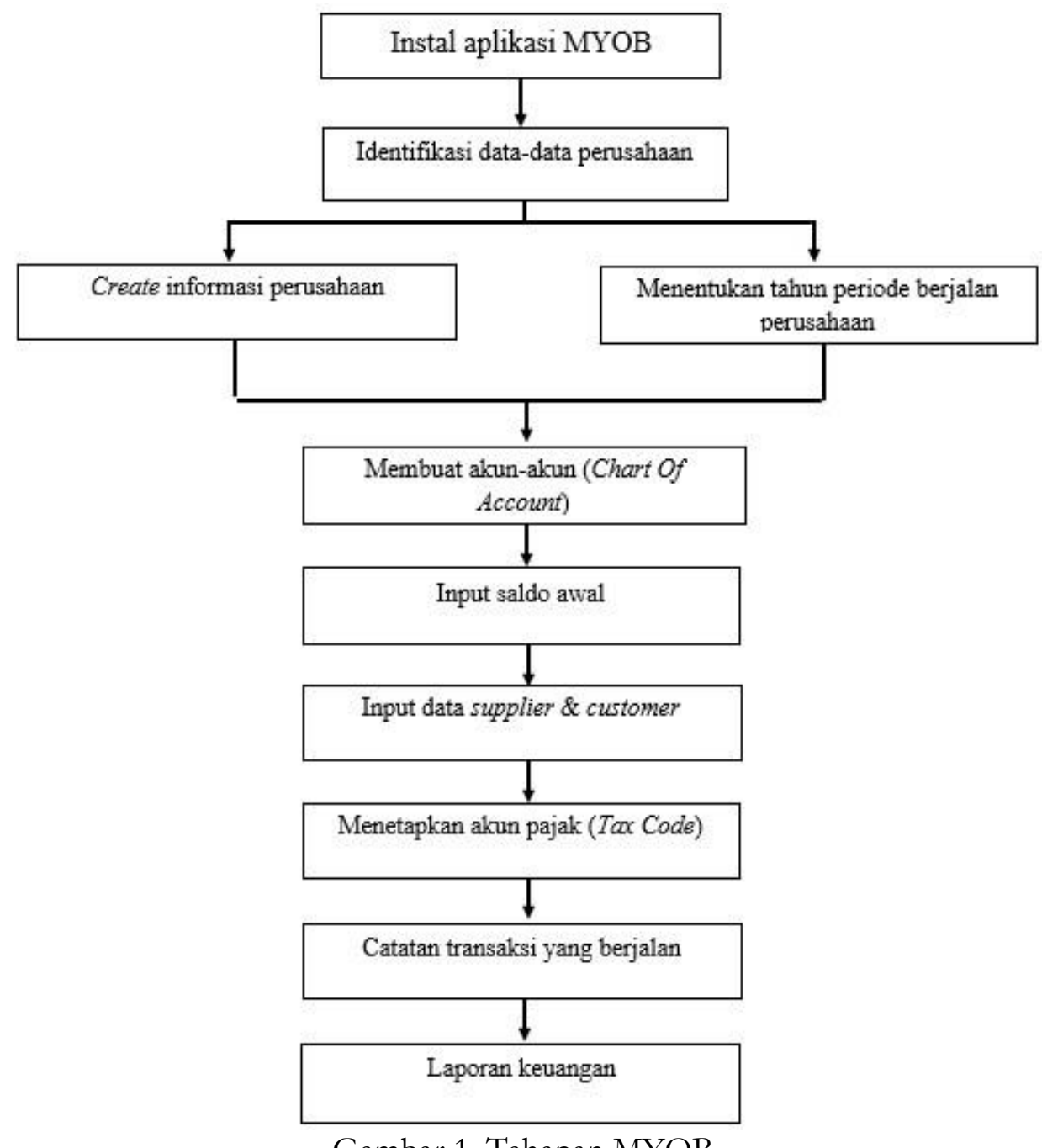

Gambar 1. Tahapan MYOB

\section{Hasil dan Pembahasan}

Dalam melakukan usahanya PT Mitra Metal Sejati menjual jasa mekanikal yaitu jasa yang berhubungan dengan kegiatan mekanikal. Customer bisa menggunakan jasanya saja untuk mekanikal atau pun melakukan pemesanan produk dengan machining fabrikasi. Machining fabrikasi merupakan proses pembuatan suatu produk jadi dengan menggabungkan atau merakit barang-barang tertentu. Dimana item atau barang dibuat dari bahan baku material mentah yang masih berbentuk plat, pipa, baja, aluminium, dan jenis logam lainnya atau barang setengah jadi dari komponen yang sudah siap 
dipakai. Machining fabrikasi terdiri dari serangkaian pekerjaan yang dikerjakan secara bertahap berdasarkan gambar atau design yang telah dibuat dengan ukuran yang sesuai yang terdiri dari proses marking, cutting, drilling, assembling, welding, finishing, blasting, dan painting. Contoh produk yang dihasilkan seperti gear, bushing, stopper conveyor, dan lain-lain sesuai permintaan customer.

\section{Flowchart yang berjalan pada perusahaan}

Sistem yang berjalan untuk pembelian bahan baku material secara kredit itu sendiri berawal dari bagian produksi. Berikut merupakan flowchart pembelian bahan baku material secara kredit pada perusahaan:

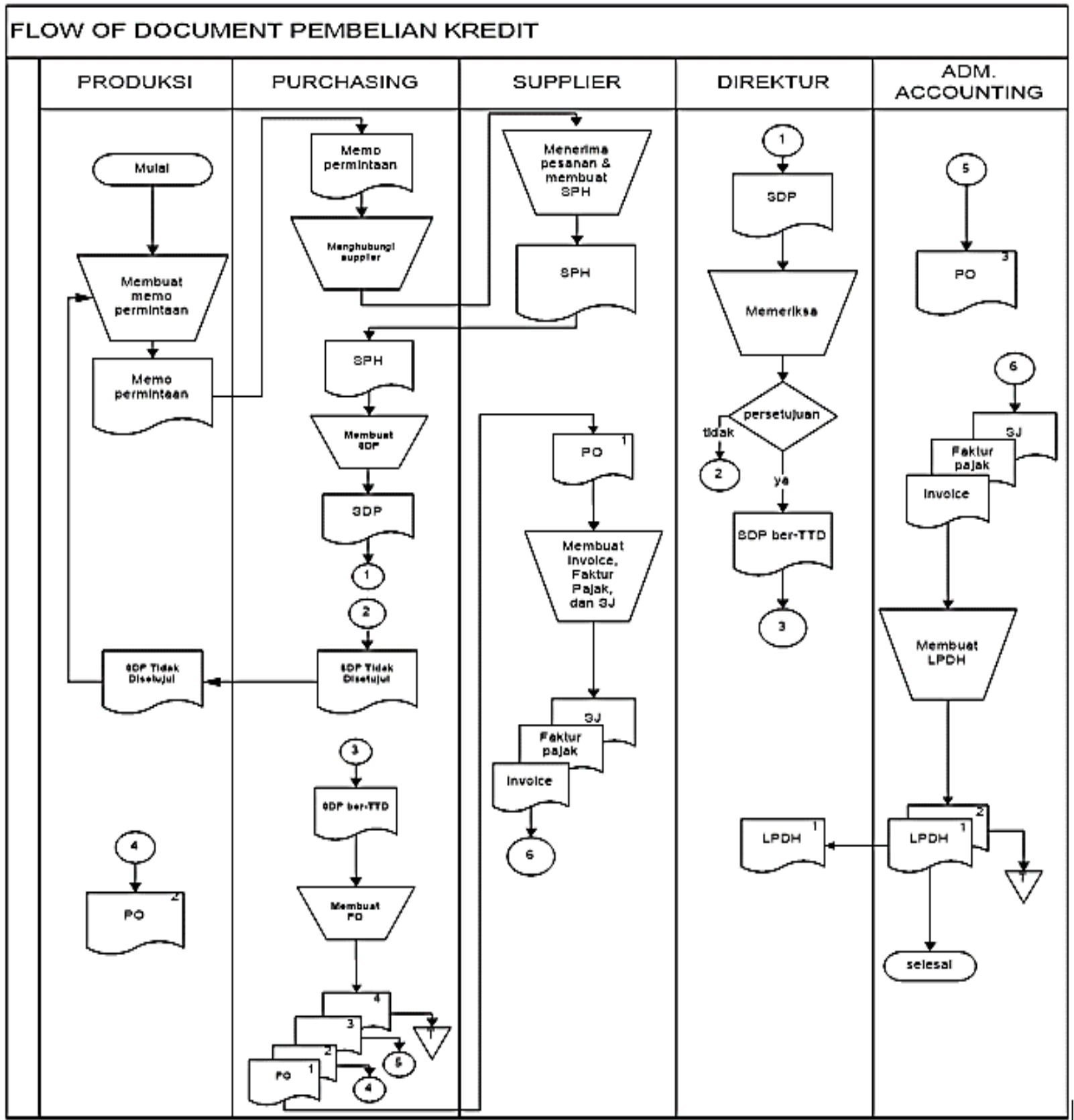

Gambar 2. Flowchart Pembelian Bahan Baku Material Secara Kredit 


\section{Gambaran Sistem Usulan}

Tujuan utama diusulkannya aplikasi keuangan yang terkomputerisasi yaitu agar proses pencatatan pembelian, pembuatan Purchase Order, hingga laporan pembelian dan utang pada PT Mitra Metal Sejati bisa dilakukan secara otomatis dan cepat sehingga mempercepat waktu pengerjaannya. Manfaat dari penggunaan aplikasi MYOB Accounting ini adalah aplikasi ini sangat cocok digunakan oleh perusahaan menengah.

\section{Prosedur Yang Diusulkan}

Penulis mengusulkan Flow of System pencatatan pembelian kredit pada PT Mitra Metal Sejati yang dapat dilihat seperti gambar dibawah ini:

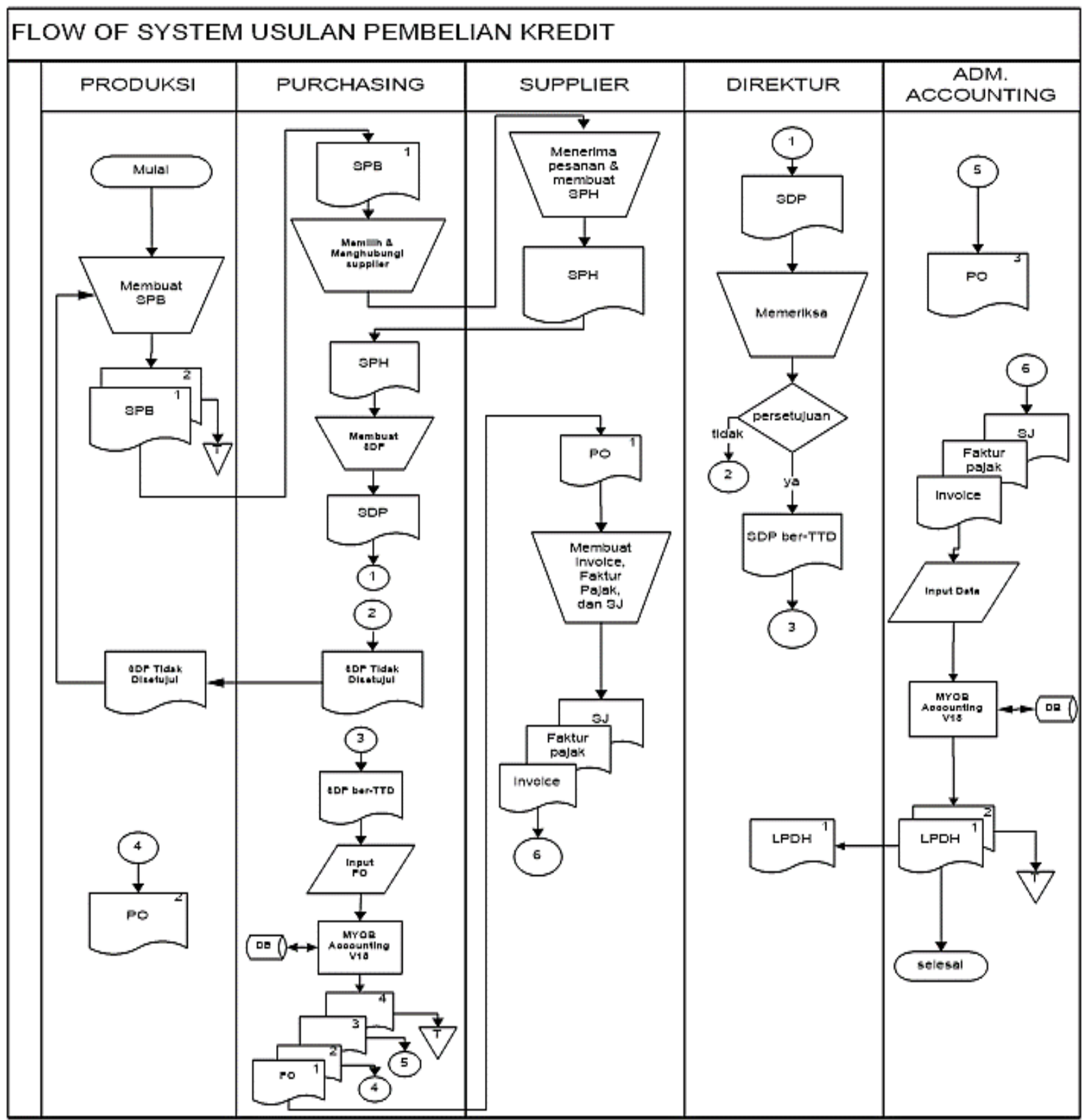

Gambar 3. Flow Of System Usulan Pembelian Kredit 


\section{Implementasi Program/Sistem}

1. Tampilan Awal MYOB

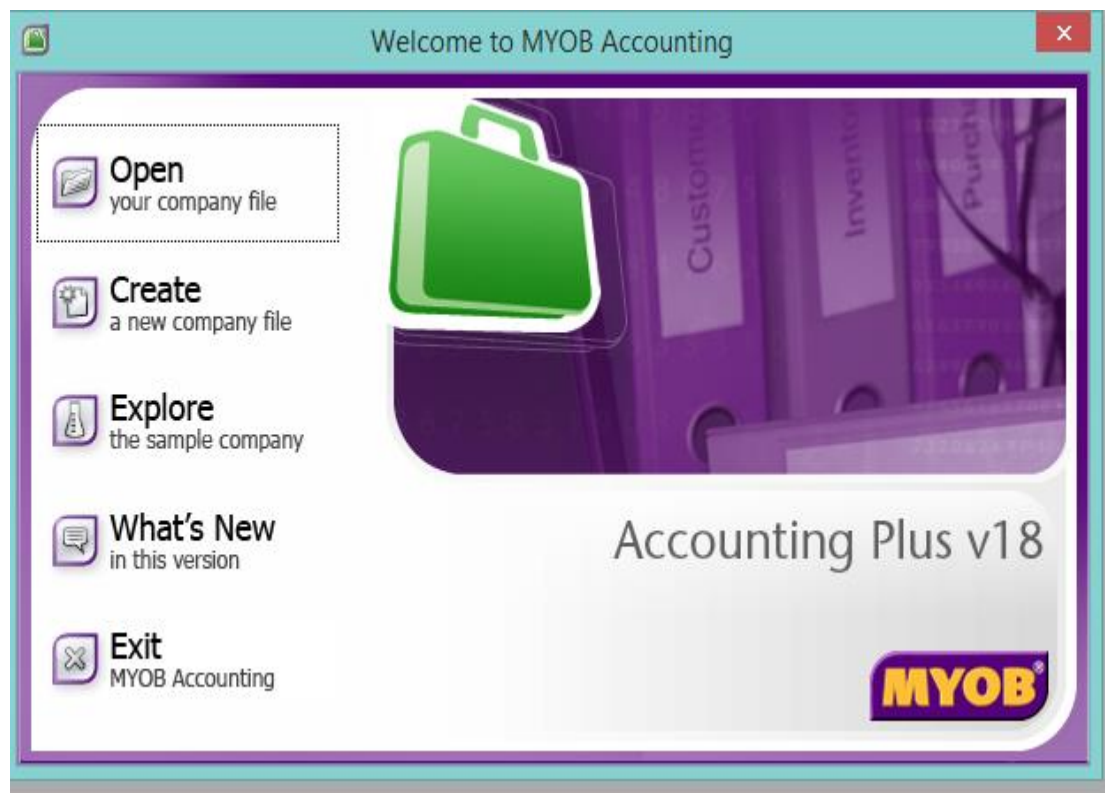

Gambar 4. Tampilan Awal MYOB

\section{Tampilan Company Informaton}

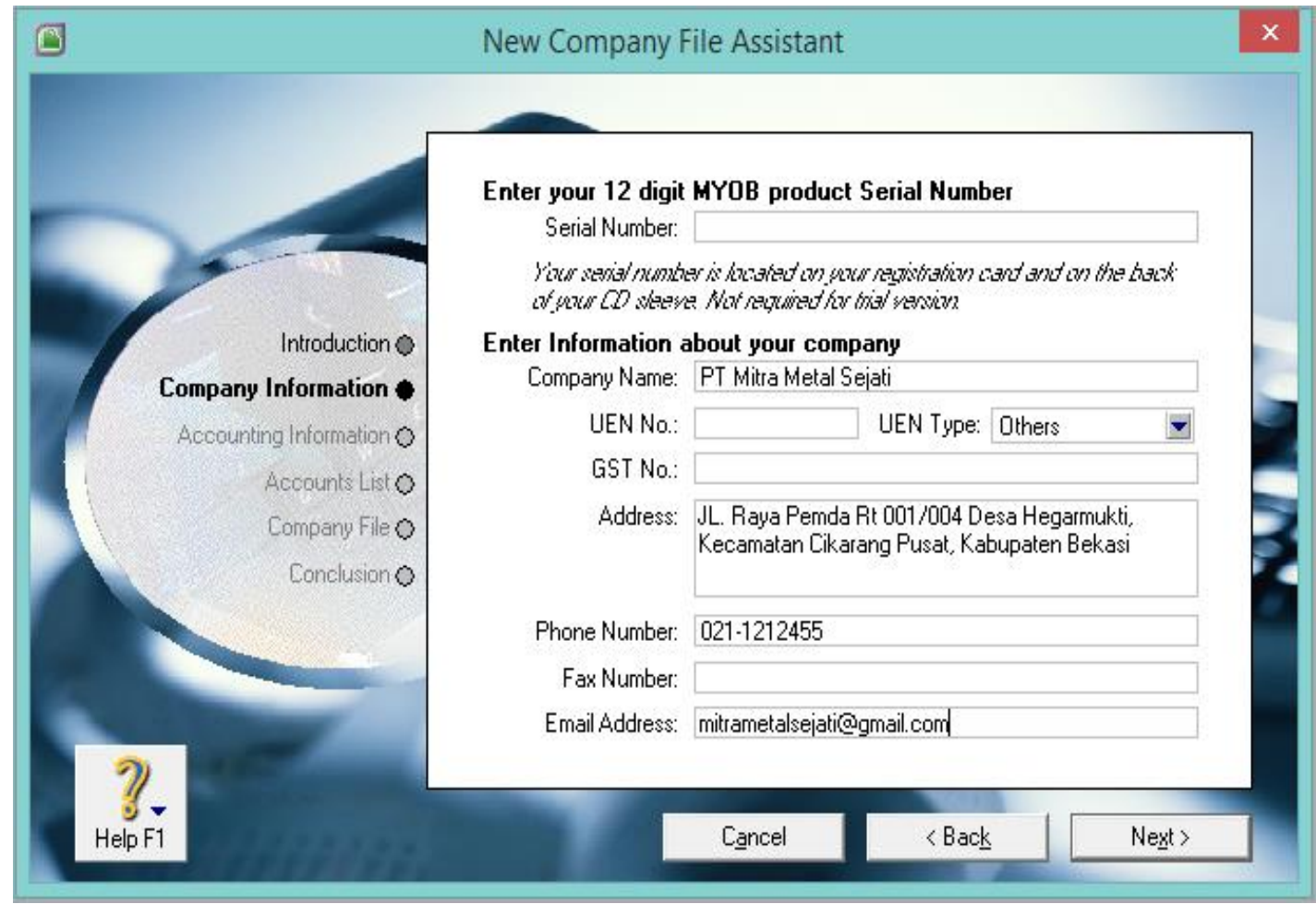

Gambar 5. Tampilan Company Informaton 
Arif Maulana Yusuf 1, Yeny Rostiani 2, Rahmat Gunawan ${ }^{3}$, Renanda Claudia 4 @ is The Best: Accounting Information Systems and Information Technology Business Enterprise ISSN: 2252-9853 (Print) | ISSN: 2656-808X (Online)

\section{Tampilan Menu Utama MYOB}

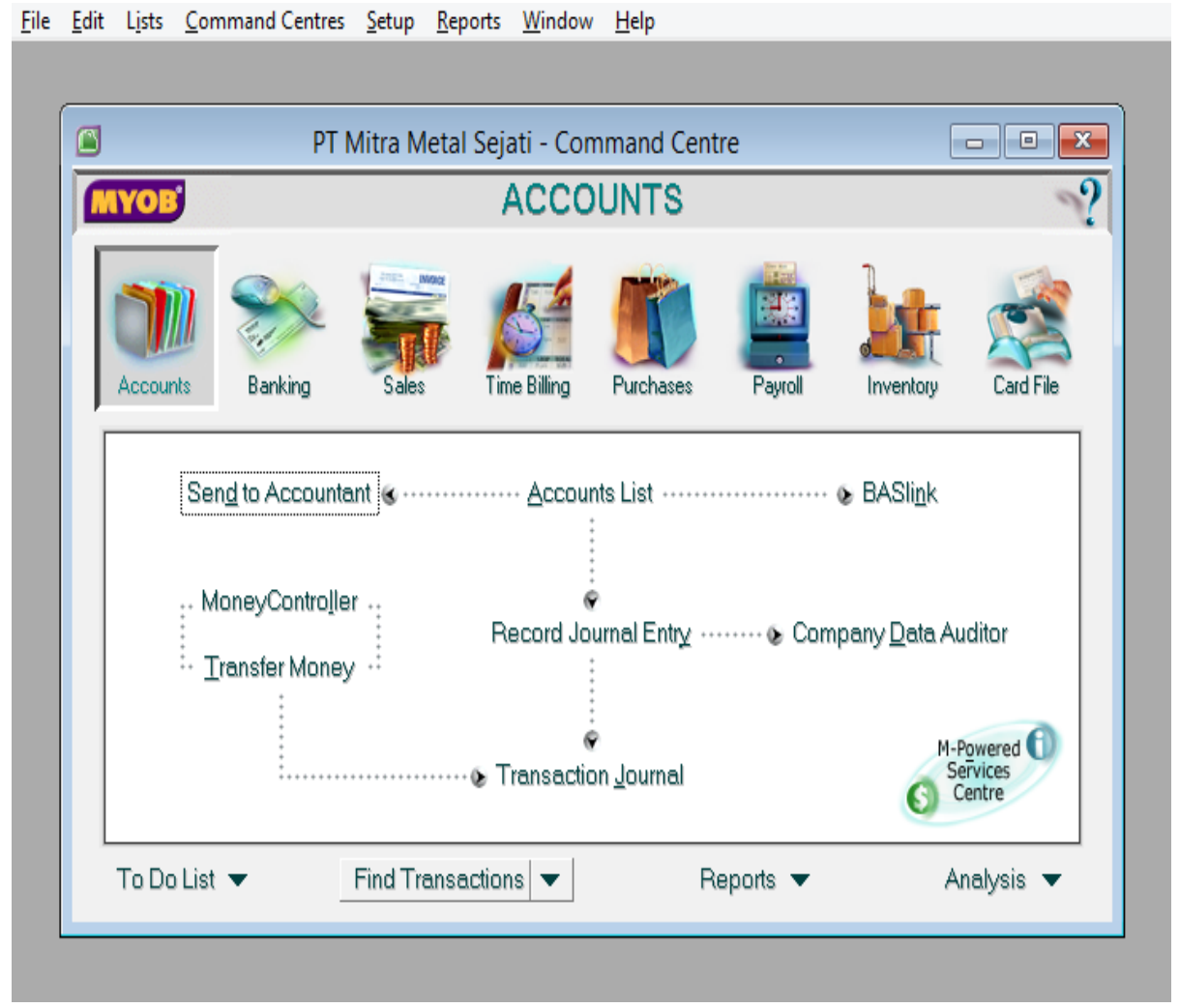

Gambar 6. Command Centre

4. Tampilan Account List

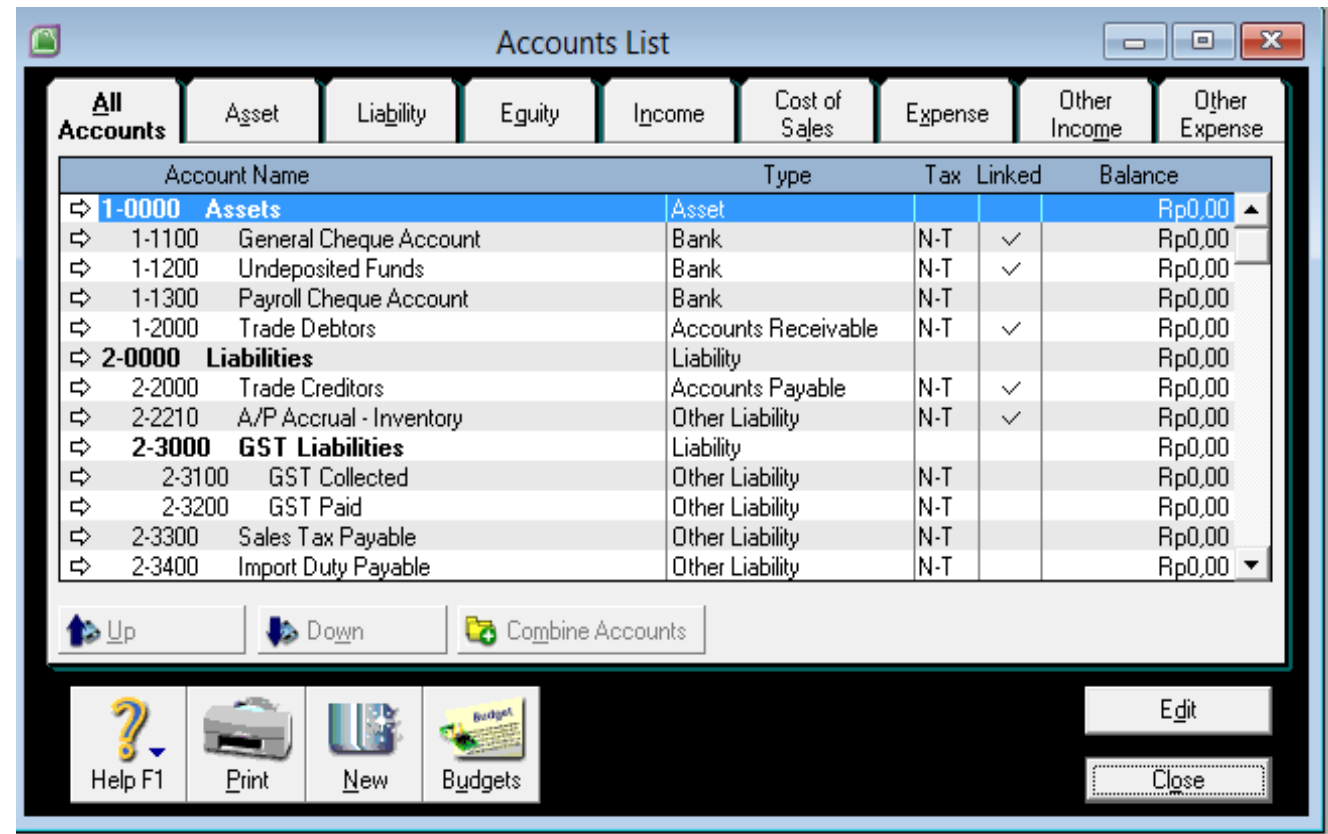

Gambar 7. Account List 
Arif Maulana Yusuf 1, Yeny Rostiani 2, Rahmat Gunawan 3 , Renanda Claudia 4

@is The Best: Accounting Information Systems and Information Technology Business Enterprise

ISSN: 2252-9853 (Print) | ISSN: 2656-808X (Online)

5. Tampilan All Account

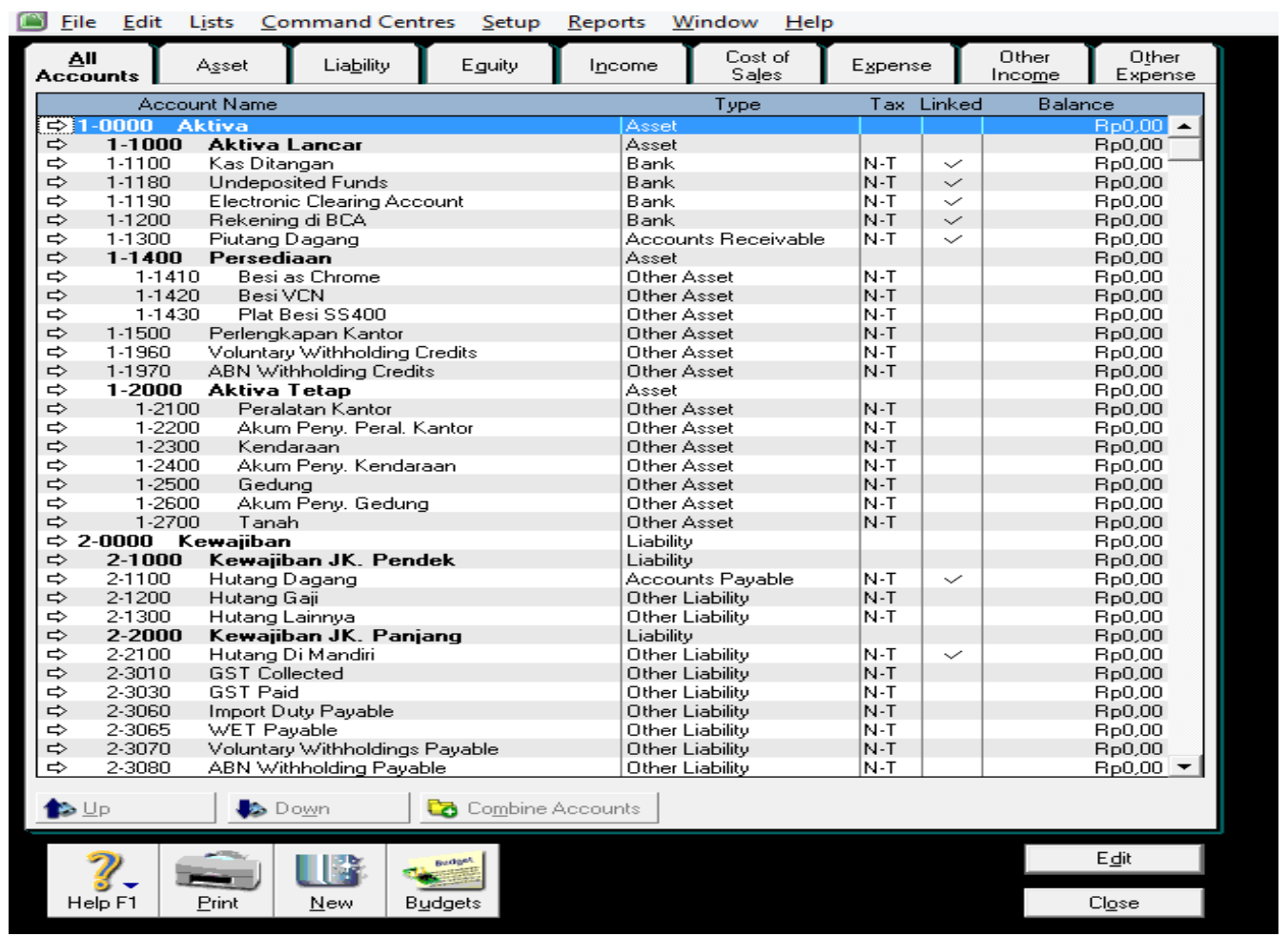

Gambar 8. All Account

6. Tampilan Cards List

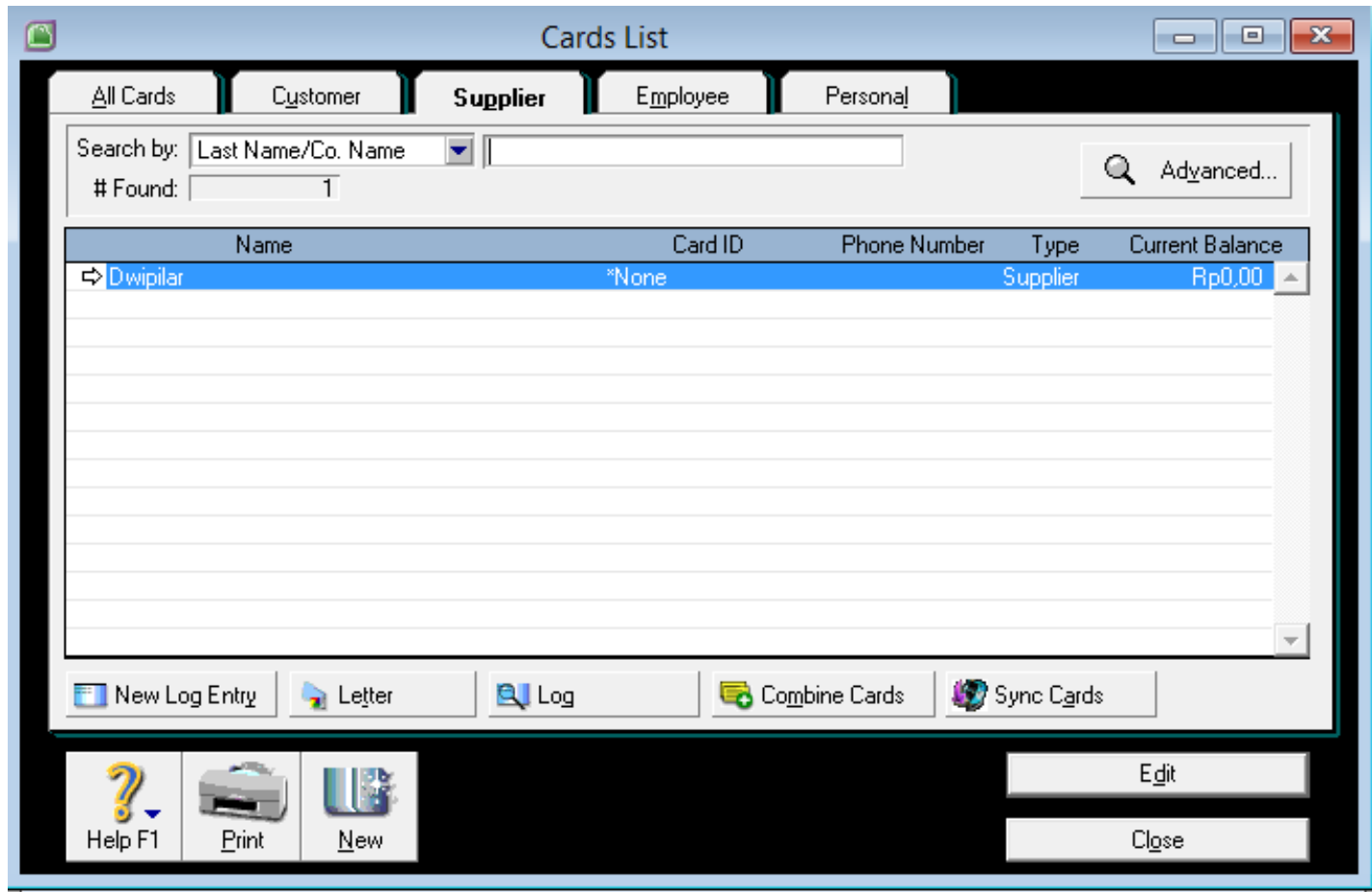

Gambar 9. Cards List

Volume 6 Nomor 1 (2021) Hal. 1-15

Attribution-ShareAlike 4.0 International. Some rights reserved 
Arif Maulana Yusuf 1, Yeny Rostiani 2, Rahmat Gunawan ${ }^{3}$, Renanda Claudia 4

@is The Best: Accounting Information Systems and Information Technology Business Enterprise

ISSN: 2252-9853 (Print) | ISSN: 2656-808X (Online)

7. Tampilan Account Opening Balance

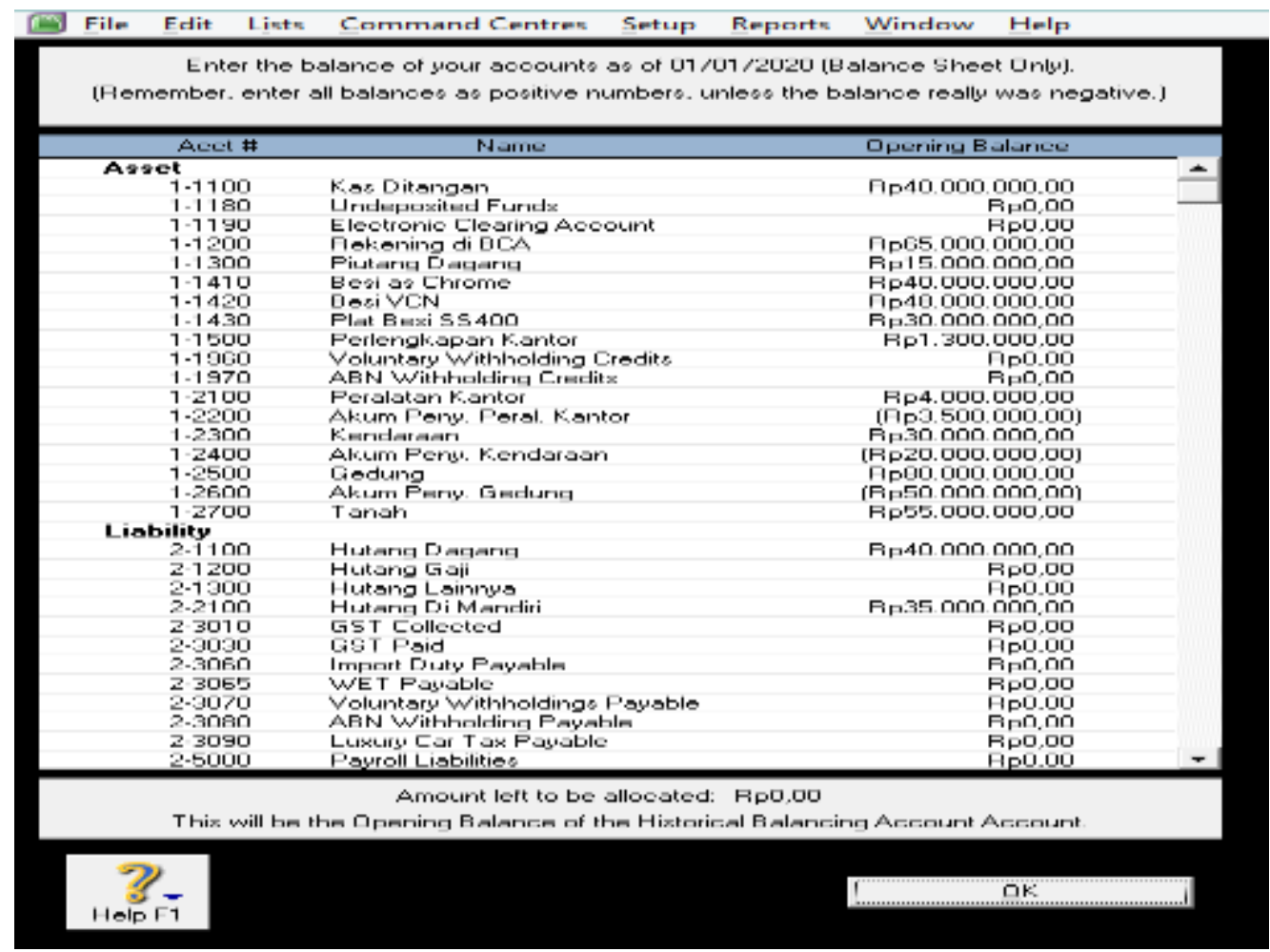

Gambar 10. Account Opening Balance

8. Tampilan Item Information

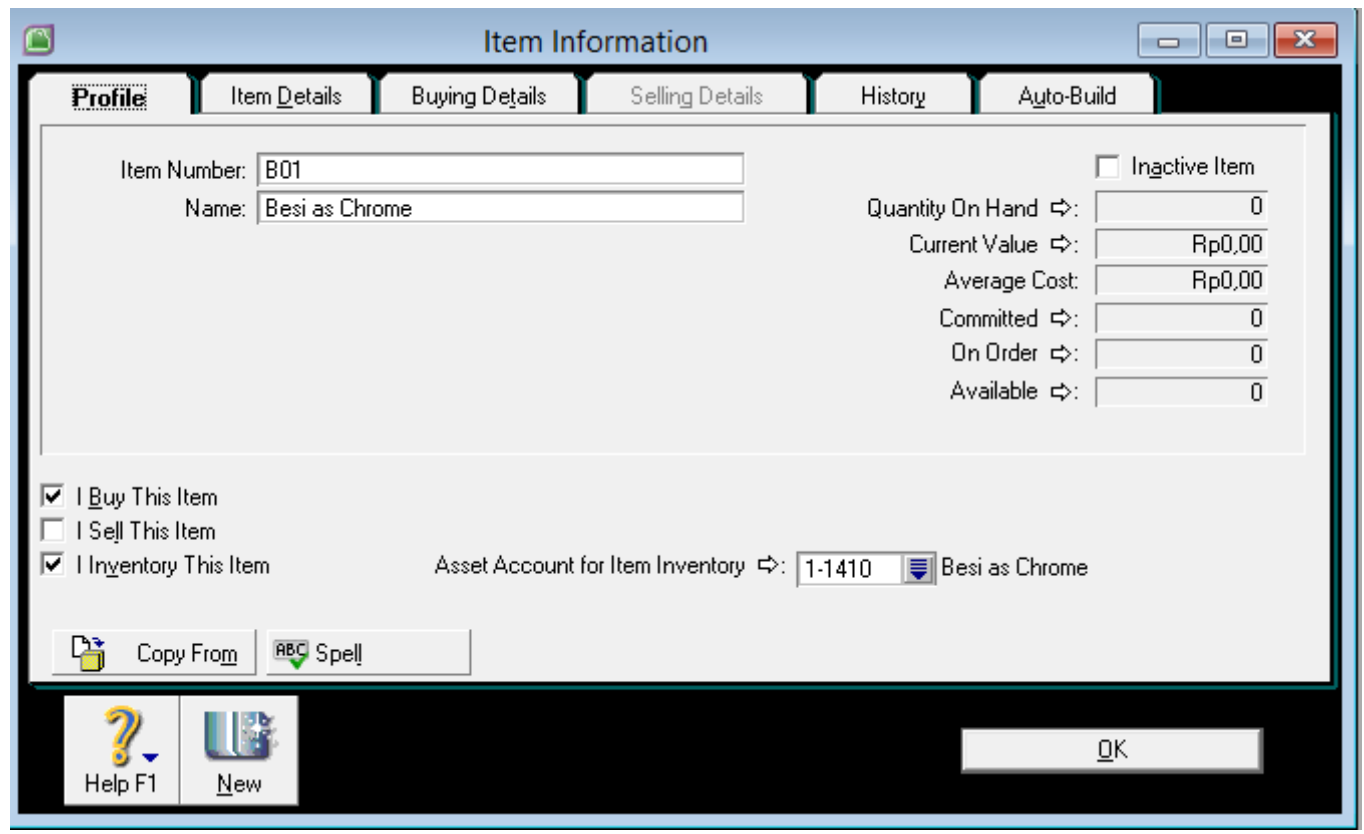

Gambar 11. Item Information

Volume 6 Nomor 1 (2021) Hal. 1-15

Attribution-ShareAlike 4.0 International. Some rights reserved 
Arif Maulana Yusuf ${ }^{\text {, }, ~ Y e n y ~ R o s t i a n i ~}{ }^{2}$, Rahmat Gunawan ${ }^{3}$, Renanda Claudia 4

@ is The Best: Accounting Information Systems and Information Technology Business Enterprise

ISSN: 2252-9853 (Print) | ISSN: 2656-808X (Online)

\section{Tampilan Adjust Inventory}

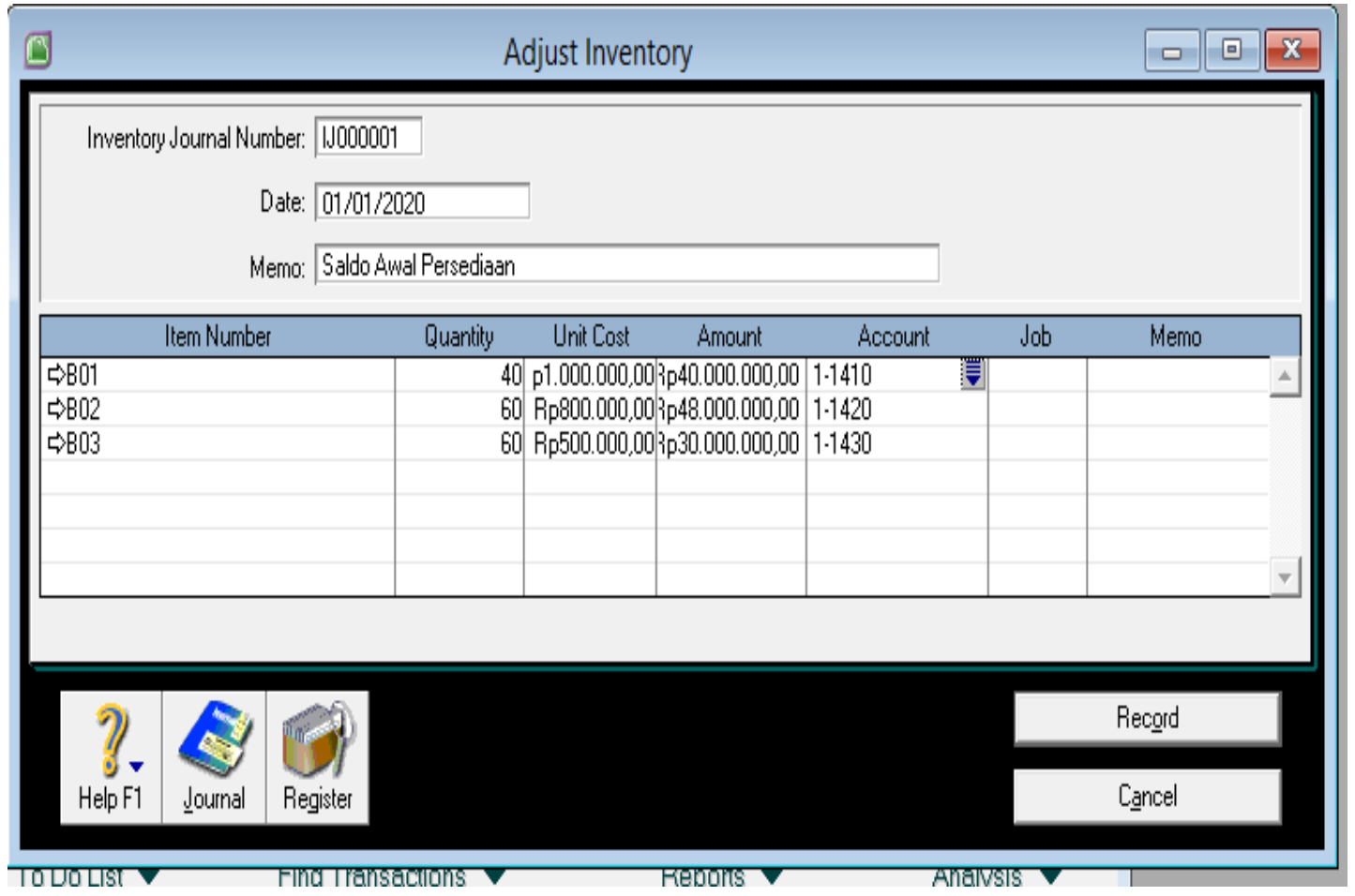

Gambar 12. Adjust Inventory

10. Tampilan Purchase

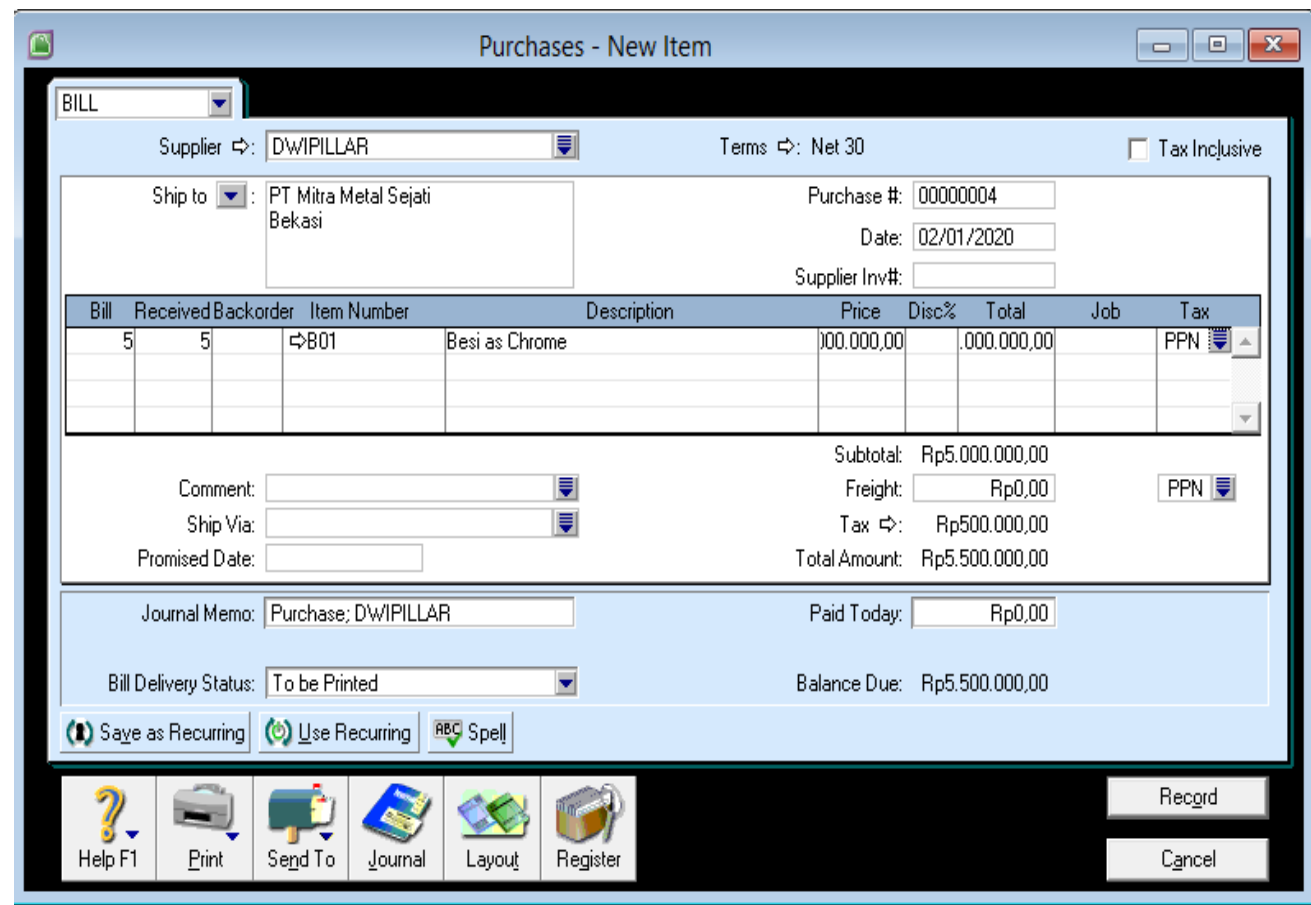

Gambar 13. Enter Purchase

Volume 6 Nomor 1 (2021) Hal. 1-15

Attribution-ShareAlike 4.0 International. Some rights reserved 
Arif Maulana Yusuf 1, Yeny Rostiani 2, Rahmat Gunawan ${ }^{3}$, Renanda Claudia 4

@is The Best: Accounting Information Systems and Information Technology Business Enterprise

ISSN: 2252-9853 (Print) | ISSN: 2656-808X (Online)

\section{Tampilan Print Preview Purchase Order}

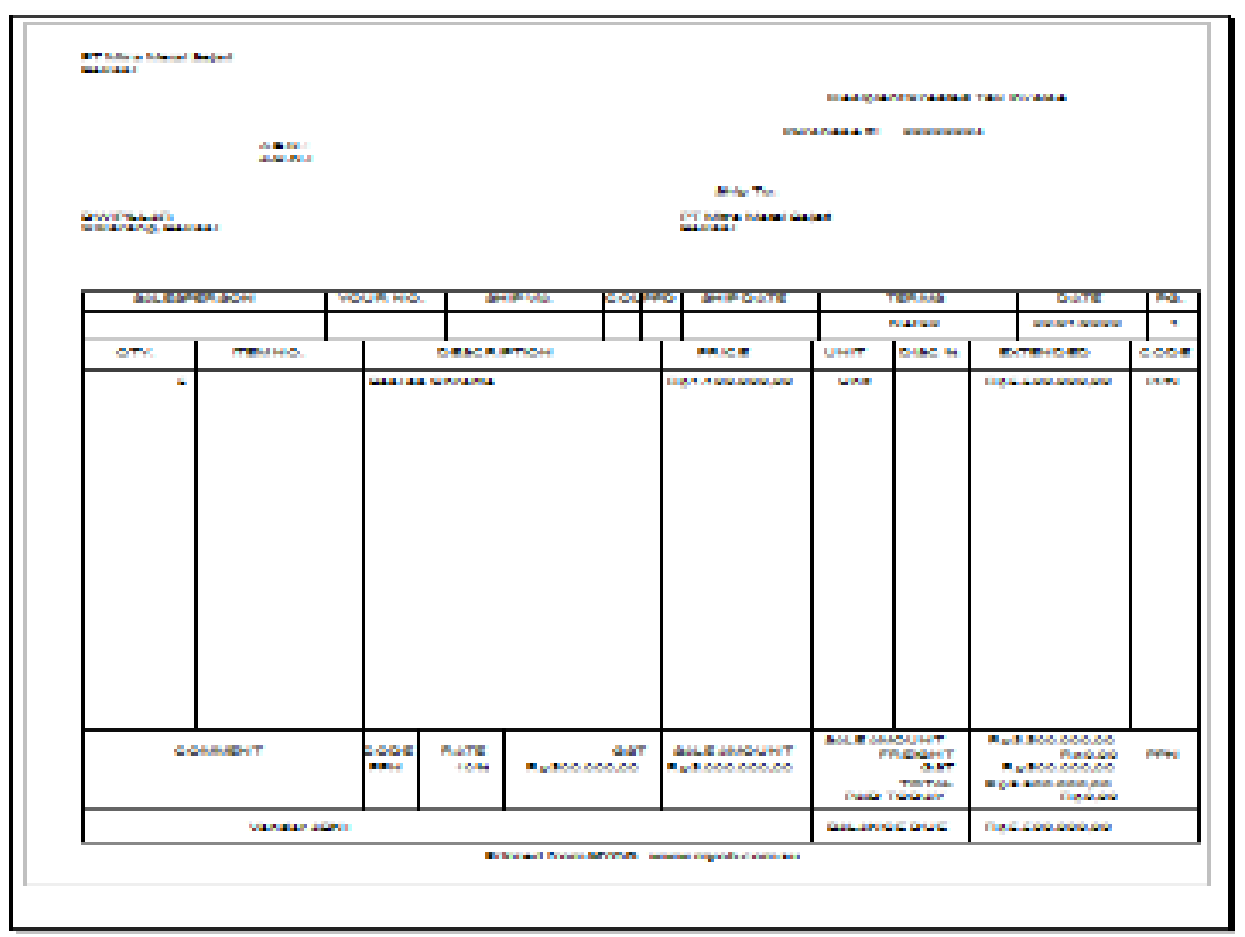

Gambar 14. Print Preview Purchase Order

\section{Tampilan Pay Bill}

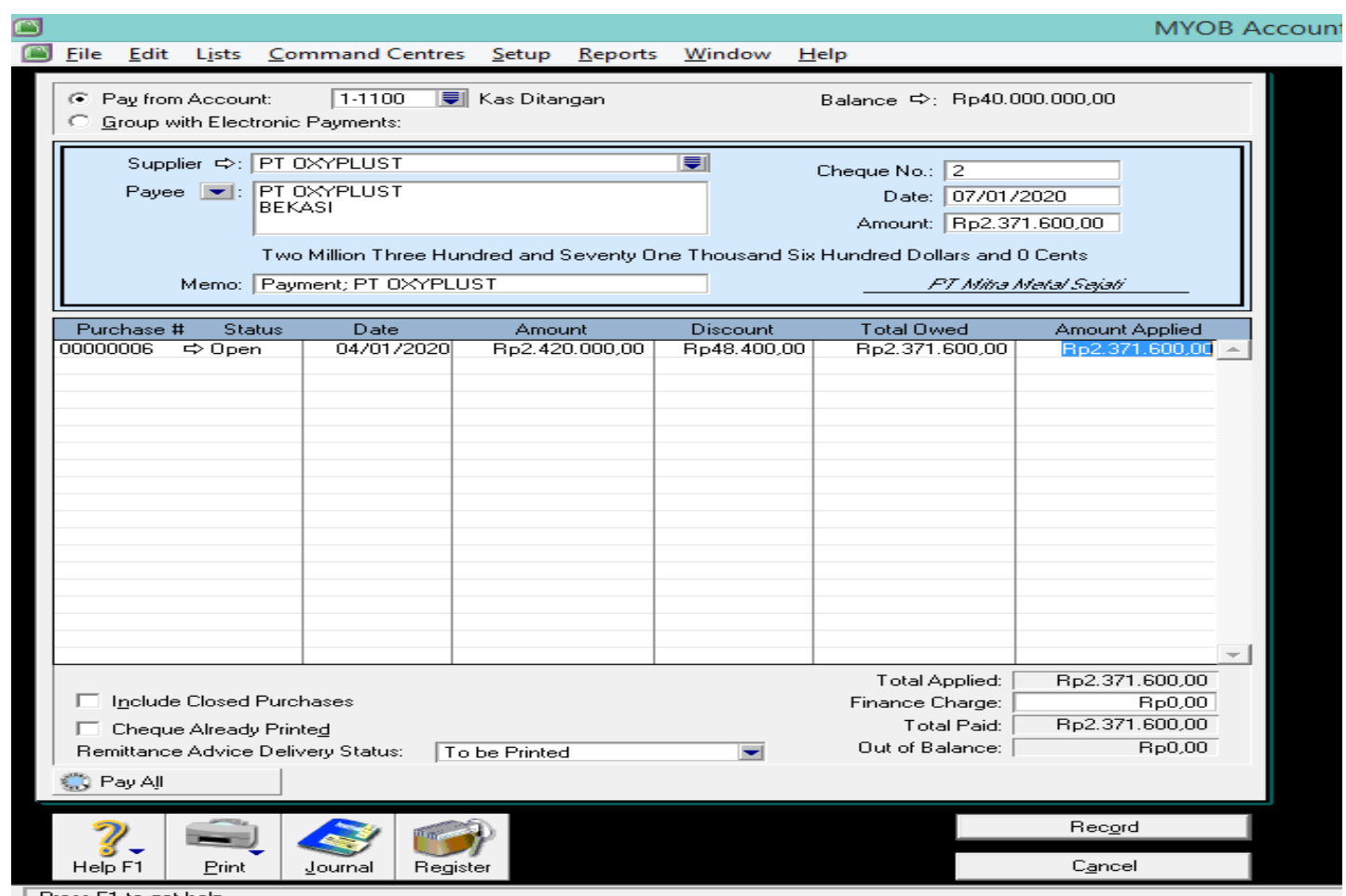

Gambar 15. Pay Bill

Volume 6 Nomor 1 (2021) Hal. 1-15 
13. Tampilan Aging Summary

\section{PT Mitra Metal Sejati \\ Bekasi \\ Aged Payables [Summary]}

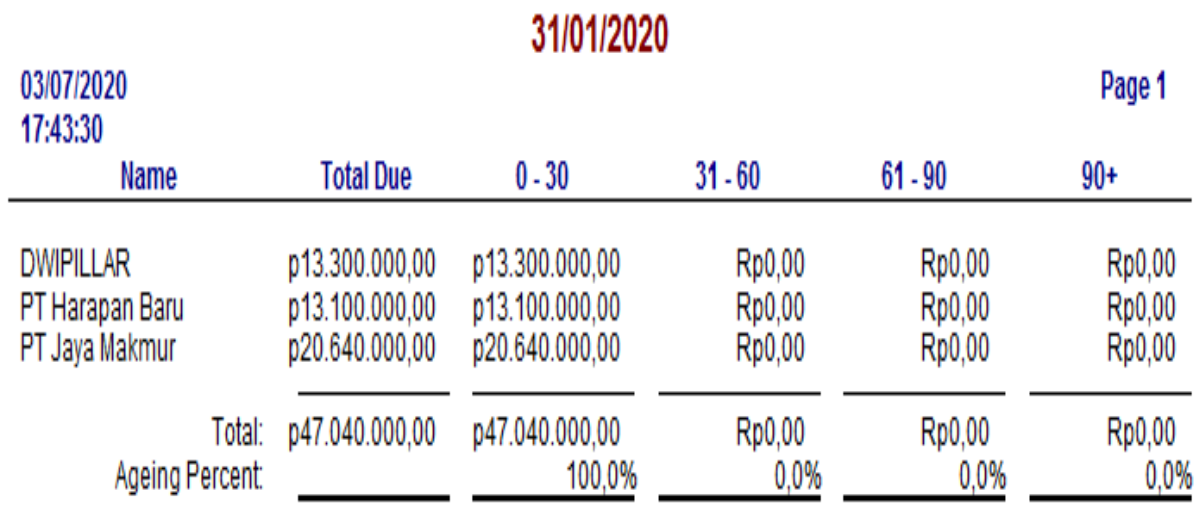

Gambar 16. Aging Summary

14. Tampilan Item Purchases Summary

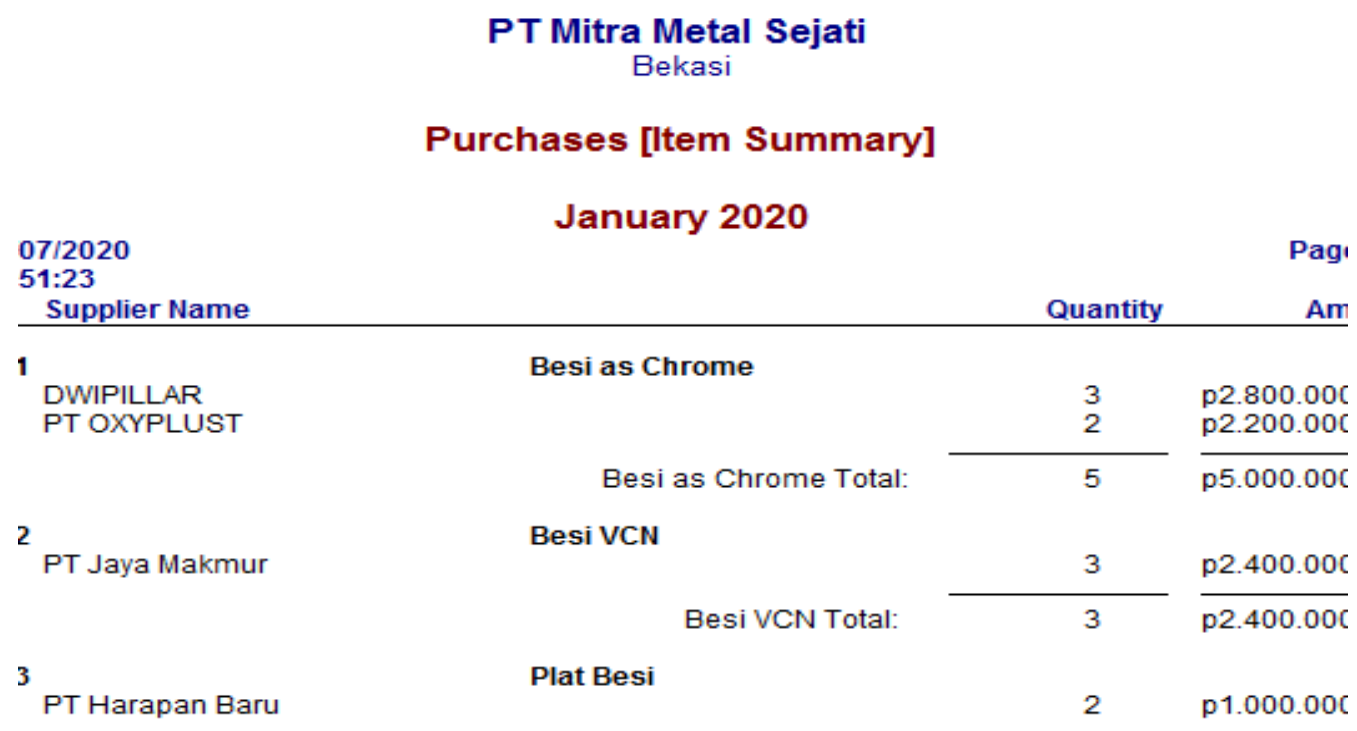

Gambar 17. Item Purchases Summary 
15. Tampilan All Purchases

\section{PT Mitra Metal Sejati \\ Bekasi}

\section{Purchase Register [All Purchases]}

\begin{tabular}{|c|c|c|c|c|c|c|c|}
\hline & & & & & & & \\
\hline $\begin{array}{l}0310712020 \\
18: 07: 00\end{array}$ & & & & & & & Page 1 \\
\hline Date & PO\# & Supplier Inv\# & Supplier Name & Amount & Amount Due & Status & Received \\
\hline 01/01/2020 & 00000001 & & DWIPILLAR & $p 10.000 .000,00$ & p10.000.000,00 & Open & \\
\hline 01/01/2020 & 00000002 & & PT Harapan Baru & p12.000.000,00 & p12.000.000,00 & Open & \\
\hline $01 / 01 / 2020$ & 00000003 & & PT Jaya Makmur & p18.000.000,00 & p18.000.000,00 & Open & \\
\hline $02101 / 2020$ & 00000004 & & DWIPILLAR & p5.500.000,00 & p3.300.000,00 & Open & $x$ \\
\hline 02/01/2020 & 00000005 & & PT Harapan Baru & p1.100.000,00 & p1.100.000,00 & Open & $x$ \\
\hline 04/01/2020 & 00000006 & & PT OXYPLUST & p2.420.000,00 & $R p 0,00$ & Closed & $x$ \\
\hline 07/01/2020 & 00000007 & & PT OXYPLUST & $(\mathrm{Rp} 48.400,00)$ & $R p 0,00$ & Closed & \\
\hline 08/01/2020 & 00000008 & & DWIPILLAR & p2.200.000,00) & $R p 0,00$ & Closed & \\
\hline 10/01/2020 & 00000009 & & PT Jaya Makmur & p2.640.000,00 & p2.640.000,00 & Open & $x$ \\
\hline & & & & & 0,00 & & \\
\hline
\end{tabular}

Gambar 18. All Purchases

\section{Penutup}

Penerapan aplikasi MYOB pada PT Mitra Metal Sejati untuk pencatatan transaksi pembelian kredit dan hutang menjadikan prosesnya lebih mudah, perusahaan dapat lebih mudah dalam mengambil keputusan karena pencatatan oleh aplikasi sudah sesuai dengan standar perusahaan. Penggunaan aplikasi dapat menghasilkan laporan yang cepat dan akurat, karena pencatatan diinput kedalam aplikasi sehingga laporan dapat langsung di tampilkan. Sedangkan, pembuatan laporan secara manual memakan waktu yang cukup lama karena ketidak akutan data yang mengharuskan melakukan pengecekan ulang. Kekurangan yang masih di jumpai penelitian yaitu belum maksimalnya penggunaan aplikasi MYOB karena terkendala pegawai yang dapat mengoperasikannya masih terbatas. Peneliti berharap penggunaan MYOB dapat mempercepat dalam pembuatan laporan yang di butuhkan oleh perusahaan, tidak ada keterlambatan lagi karena semua data sudah tecatat dalam aplikasi, sehingga masalah yang selama ini sering terjadi dapat dihindari.

\section{Daftar Pustaka}

[1] M. M, "PERKEMBANGAN TEKNOLOGI DALAM INDUSTRI MEDIA," J. Tek. Ind., 2012.

[2] A. K. Widagdo, A. Widodo, and M. Ismail, "Sistem Akuntansi Pengelolaan Dana Desa," J. Ekon. dan Bisnis, 2016. 
[3] NURHAYATI, "Peranan Sistem Informasi Akuntansi Terhadap Pengambilan," Maj. Ilm. Politek. Mandiri Bina Prestasi, 2018.

[4] A. Haryana, A. Rochman, and A. Setyaningsih, "Perancangan sistem informasi perencanaan dan pengendalian bahan baku pada home industri," J. Sisfotek Glob., 2017.

[5] D. Nuryanti and R. Suprantiningrum, "Analisis Dan Perancangan Sistem Informasi Akuntansi Penjualan, Piutang Dan Penerimaan Kas (Studi Kasus pada UD.Praktis di Magetan)," J. Ilm. UNT AG Semarang, 2016.

[6] Pipit, “AKuntansi," Igarss 2014, 2016.

[7] A. I. Tyas, M. L. D. E. Revita, and I. Ariyati, "Sistem Informasi Pengolahan Data Akuntansi Perusahaan Menggunakan Zahir Accounting Versi 5.1," Fundam. Manag. J. Fundam. Manag. J. ISSN eISSN 2540-9220, 2019.

[8] I. Widiastuti, "Sistem Informasi Akuntansi Berbasis Komputer," Bhirawa. Vol. 2. No. 2 Ed. Desember 2015, 2015.

[9] Setyorini, Pengantar Sistem Informasi Akuntansi. 2016.

[10] Andi, "Komponen SIA," in Sistem Informasi Akuntansi: Esensi dan Aplikasi, 2017.

[11] A. M. Yusuf and N. Dini, "TETAP MENGGUNAKAN METODE GARIS LURUS BERBASIS VB . NET PADA CV GINANJAR SEJAHTERA MANDIRI KARAWANG," vol. 16, pp. 38-45, 2021.

[12] A. Chosyali and T. Sartono, "OPTIMALISASI PENINGKATAN KUALITAS KREDIT DALAM RANGKA MENGATASI KREDIT BERMASALAH,” LAW REFORM, 2019.

[13] G. Susila, "Dampak Tingkat Perputaran Kas, Perputaran Piutang dan Jumlah Nasabah Kredit terhadap Profitabilitas," JLA (Jurnal Ilm. Akuntansi), 2020.

[14] H. Lesmana, W. Erawati, H. Mubarok, and E. Suryanti, "Implementasi ABSS Accounting Pada Laporan Keuangan CV One Solution Media,” vol. 5, pp. 166-180, 2020.

[15] M. Zaenuri, "Penerapan Aplikas Software Myob Pada Perusahaan Dagang ( Toko Angkasa Komputer )," Infokam, 2013. 